\title{
E-Musik - Kunstreligion der Moderne: Beethoven und andere Götter
}

Helmut Loos. E-Musik - Kunstreligion der Moderne: Beethoven und andere Götter. [Art Music - The Art-Religion of Modernity: Beethoven and Other Gods.] (Kassel und Basel: Bärenreiter, 2017. 160 pages. 29,95 €. ISBN: 978-3-7618-2435-1).

In his monograph E-Musik - Kunstreligion der Moderne: Beethoven und andere Götter, Helmut Loos takes on fundamental questions about the reception, comprehension and evaluation of music, defined through the concept of „art-as-religion“ in modernity. Sure enough, these questions also directly characterise key dilemmas of contemporary art reception and define the aesthetic judgment of today. In the past, the author has already tackled the aforementioned issues on different occasions, but in this book he draws on his earlier contributions (previously scattered throughout various scientific journals and edited volumes), and presented his ideas in a more clear and accessible manner.

The monograph, as the title suggests, discusses the question of so-called "classical", "artistic" or "serious" music in the context of art-as-religion in modernity. The difficulty of translating - and only partly adequately - the German term "E-Musik” (roughly „high art music" in English) already indicates a problematic, and in recent times increasingly problematised conception of art, and especially music as an insufficient, inconsistent, contradictory and fuzzy substitute for a religious or even ideological principle, which is the guiding principle of society as a whole. What the author formulates in this book is a metacritique of the comprehension of art, and with it music, the kind of music that is defined by the function of the autonomous resolution of everything functional. In his analysis, Loos is no doubt aware of the fact that every analytical reflection - whether set as a critical mirror of the individual or meant as a dissection of a collective consciousness - is always also subjective, always in some way personally conditioned. Still, this does not mean that the author is not willing to boldly bet his good name on a harsh and relentless critique of the modern conception of art, however undoubtedly compromised it might be by his own interpretative position. It is as if the author's subjectively foregrounded thesis dismisses the appearance of the falsely objective reality, often hidden behind a pseudoscientifically grounded expertise, on which the modern interpretation of art, with its superior reception and critical evaluation, often falls back, as a kind of superstitious mantra, at the same time refusing to 
acknowledge its own contradictory and ill-conceived practice. Although in his elaboration, Loos does not explicitly side with or against one of the emphasised aesthetic positions - he essentially tries to stay true to the principle of objective distance, which he achieves throughout the book - he does remain, again according to his principles, explicitly critical and tenaciously harsh. He doubts the "scientific value of the emphatic musical-historical approach" (p. 13), as he points out in the introduction, and instead constructs his own critical position that has been taking form since his earlier research, gradually becoming an increasingly profiled basis on which the entire monograph is indeed grounded. Loos thus distances himself from a superficial critique of individual creative decisions but at the same time closely verifies their aesthetic principles, upon which the dominant aesthetic platform is based:

Let me say it once more very clearly: It is not my intention to criticise particular types of music or different views on music, they all have their respective eligibility and can be defended on the basis offree and individual decisions. I criticize the self-certitude with which certain positions regard their superior value as scientifically proven and deduce from this what we can call a fundamentalist arrogance, which is accompanied by contempt towards those with different opinions. (p. 13)

Loos traces the origins of such aesthetic-philosophical considerations to the Enlightenment and with it the rising bourgeoisie that bestowed upon music the status of an „emphatic art“. It was thus transformed from a symbol, or a human creative answer to the metaphysical, into the actual transcendence per se, as formulated by the critic Ludwig Tieck. Music, which seemed the most "absolute" of all the arts, the farthest from concrete social being, could at the same time become the ambitious bourgeois medium of self-assertion in the concrete political circumstances of harsh censorship, in the times of the Restoration after 1815, as it could gather larger groups of listeners. The historical framework had thus contributed to the gradual aesthetic turn towards art-as-religion, in which autonomous music was attributed a special place. Loos points to the guiding concepts of modernity that on the one hand established music, and on the other hand increasingly and explicitly legitimised its image: autonomy, rationality, secularisation and progress, as clearly elaborated by Kant. But their direct transfer into the vocabulary of aesthetic categories, as Loos demonstrates, became problematic, and the critique of this process can in fact be regarded as the crux of his discussion.

In the book, the author gradually tackles the most diverse aspects of the conception of art that is nowadays still largely considered to be self-evident, of its reception and its aesthetic normative system. While doing this, he takes up several "sacred cows" of modern artistic music without reservations. First, he begins with the definition and differentiation of the terms "sacred music" (heilige Musik) and "serious music" (ernste Musik), spun as an increasingly concrete discourse. Afterwards, he weaves the discussion of evolutionary theory and its uncritical transfer into musical aesthetics into the debate, which turned the greater or lesser aesthetic persuasiveness into another criterion for the measurement of historical progress. Loos sees the same background thinking in numerous musical writers who tragically marked the history of man with 
the ideas of the superiority of the superman. Here, he is especially harsh towards traces of the progressive-Darwinian ideas in the more or less contemporary (predominantly German) musical historiography, and in modern art production. Loos is especially critical towards all ideological antagonisms, represented by dichotomies such as progressive-conservative, high-low, serious-entertaining, atonal-tonal etc., and towards the associated belief in the historical necessity of the break with tonality. Through this, he also analyses the broader worldview context that is in his eyes supported even by the tendentially distorted musical-analytical view (which he convincingly proves with Berg's Wozzeck). But the author's main focus is on the processes of the apotheosis of musical ideals in the context of religious models of art-as-religion, as is shown in the Prometheus character in music, in Wagner reception, or especially visible in the interpretation of Beethoven as the head of the musical-religious Parnassus that was erected by the bourgeoisie according to its self-image.

In his meta-analysis of the concepts of the contemporary conceptualisation of art, especially in the musical-historical tradition, Loos is delicate and accurate. His elaborations are based on a wide range of contemporary literature and exceptional knowledge of musical history, which is upgraded by an in-depth analysis of contemporary musical, aesthetic and historiographical concepts. At times it can be felt that some parts of the book have been first conceived for diverse publications, but presented anew, they make up an assemblage of interconnected images, which at the same time display a unified and purified analytical approach. Due to its forthright critique of contemporary concepts of art-as-religion and the conclusiveness of his elaborations, the book will therefore be impossible to overlook, and will be especially useful for new musicians, musicologists, composers and students of music.

Matjaž Barbo

Faculty of Arts, University of Ljubljana 